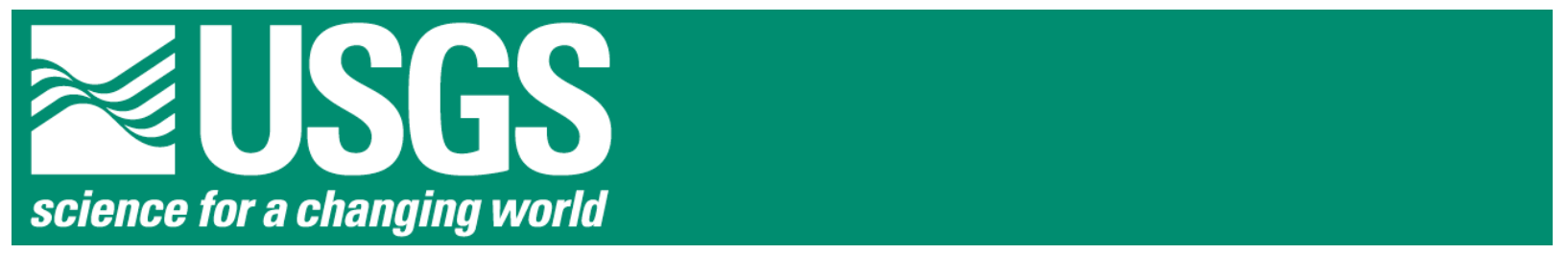

\title{
High-Resolution Topographic, Bathymetric, and Oceanographic Data for the Pleasure Point Area, Santa Cruz County, California: 2005-2007
}

By Curt D. Storlazzi, Patrick L. Barnard, Brian D. Collins, David P. Finlayson, Nadine E. Golden, Gerry A. Hatcher, Robert E. Kayen, and Peter Ruggiero.

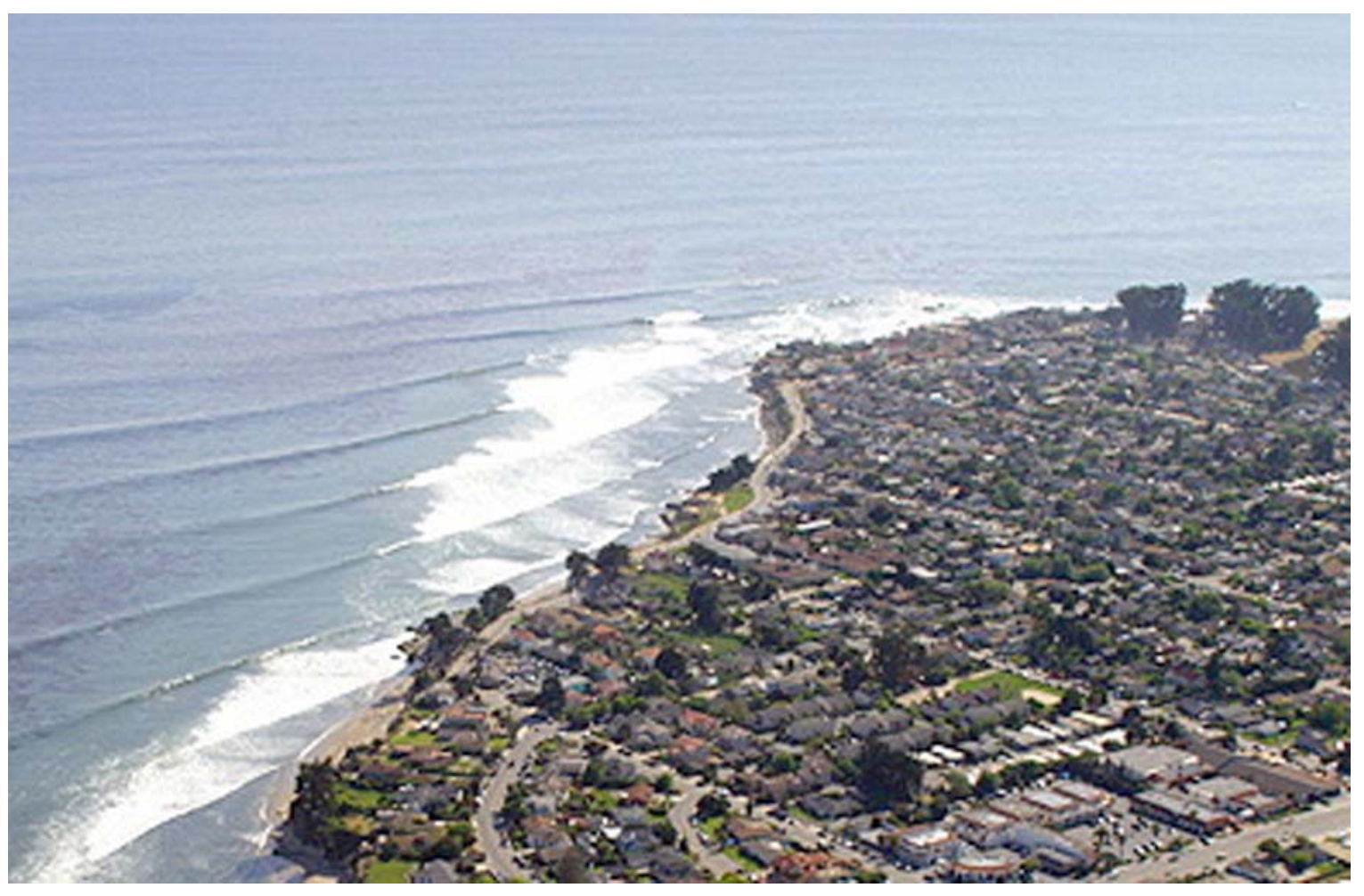

Oblique aerial photograph of the Pleasure Point area

Open-File Report 2007-1270

U.S. Department of the Interior

U.S. Geological Survey 
Other than this note, this page intentionally left blank. 


\section{High-Resolution Topographic, Bathymetric, and Oceanographic Data for the Pleasure Point Area, Santa Cruz County, California: 2005-2007}

Curt D. Storlazzi', Patrick L. Barnard', Brian D. Collins², David P. Finlayson', Nadine E. Golden', Gerry A. Hatcher ${ }^{1}$, Robert E. Kayen ${ }^{2}$, and Peter Ruggiero ${ }^{3}$.

${ }^{1}$ U.S. Geological Survey, Pacific Science Center, Santa Cruz, CA

${ }^{2}$ U.S. Geological Survey, Western Region Headquarters, Menlo Park, CA

${ }^{3}$ Oregon State University, Department of Geosciences, Corvallis, OR

Open-File Report 2007-1270

U.S. Department of the Interior

U.S. Geological Survey 


\section{U.S. Department of the Interior Dirk Kempthorne, Secretary \\ U.S. Geological Survey \\ Mark D. Myers, Director}

U.S. Geological Survey, Reston, Virginia: 2007

This report and any updates to it are available at: http://pubs.usgs.gov/of/2007/1270/

For product and ordering information: World Wide Web: http://www.usgs.gov/pubprod

Telephone: 1-888-ASK-USGS

For more information on the USGS - the Federal source for science about the Earth, its natural and living resources, natural hazards, and the environment:

World Wide Web: http://www.usgs.gov

Telephone: 1-888-ASK-USGS

Manuscript approved for publication, September 5, 2007

Any uses of trade, product, or firm names is for descriptive purposes only and does not imply endorsement by the U.S. Government.

Although this report is in the public domain, permission must be secured from the individual copyright owners to reproduce any copyrighted materials contained within this report. 


\section{LIST OF FIGURES}

FIGURE 1. Map of the study area location. $\quad 6$

FIGURE $2 . \quad$ Schematic showing the elliptical scan pattern of the ATM. $\quad 9$

$\begin{array}{lll}\text { FIGURE } 3 . & \text { Topographic lidar data acquisition and an example scan. } & 10\end{array}$

$\begin{array}{lll}\text { FIGURE } 4 . & \text { Region of topographic lidar data coverage in the study area. } & 11\end{array}$

FIGURE 5. Coastal Profiling System being prepared for data collection. 12

FIGURE 6. Coastal Profiling System survey track lines in the study area. $\quad 12$

FIGURE 7. View of the data processing shed onto the fantail of the R/V Paragon. 13

$\begin{array}{lll}\text { FIGURE } 8 . & \text { Underway view of the starboard gunnel of the R/V Paragon. }\end{array}$

FIGURE 9. Color-coded swath bathymetry of the study area. $\quad 14$

FIGURE 10. Location and image of the AWAC deployed off Pleasure Point. 15

FIGURE 11. Variation in the incident wave field during the periods of data acquisition. 16

$\begin{array}{lll}\text { FIGURE } 12 . & \text { Components of the digital imaging system. } & 17\end{array}$

$\begin{array}{lll}\text { FIGURE 13. Two merged } 8 \text { mega-pixel digital stills taken of the Pleasure Point surf breaks. } & 18\end{array}$

$\begin{array}{lll}\text { FIGURE } 14 . & \text { Video camera data from a period with small waves. } & 18\end{array}$

$\begin{array}{lll}\text { FIGURE } 15 . & \text { Video camera data from a period with large waves. } & 18\end{array}$

\section{LIST OF TABLES}

$\begin{array}{lll}\text { TABLE 1. } & \text { AWAC deployment log. } & 15\end{array}$

$\begin{array}{lll}\text { TABLE 2. Digital imaging system data acquisition statistics. } & 17\end{array}$

\section{LIST OF APPENDICES}

$\begin{array}{lll}\text { APPENDIX 1. Terrestrial Lidar System Information. } & 21\end{array}$

APPENDIX 2. Coastal Profiling System Information. 23

$\begin{array}{lll}\text { APPENDIX 3. Swath Bathymetry System Information. } & 24\end{array}$

$\begin{array}{lll}\text { APPENDIX 4. Acoustic Doppler Profiler Information. } & 26\end{array}$

$\begin{array}{lll}\text { APPENDIX 5. Digital Imaging System Information. } & 27\end{array}$

$\begin{array}{lll}\text { APPENDIX 6. } & \text { Experiment Personnel. } & 28\end{array}$ 


\section{ADDITIONAL DIGITAL INFORMATION}

For additional information on the instrument deployments, please see: http://walrus.wr.usgs.gov/infobank/a/a198pc/html/a-1-98-pc.meta.html http://walrus.wr.usgs.gov/infobank/w/w105mb/html/w-1-05-mb.meta.html http://walrus.wr.usgs.gov/infobank/p/p105mb/html/p-1-05-mb.meta.html http://walrus.wr.usgs.gov/infobank/p/p106mb/html/p-1-06-mb.meta.html http://walrus.wr.usgs.gov/infobank/p/pp106mb/html/p-p1-06-mb.meta.html http://walrus.wr.usgs.gov/infobank/f/f106mb/html/f-1-06-mb.meta.html http://walrus.wr.usgs.gov/infobank/f/f206mb/html/f-2-06-mb.meta.html http://walrus.wr.usgs.gov/infobank/f/f306mb/html/f-3-06-mb.meta.html http://walrus.wr.usgs.gov/infobank/f/f107mb/html/f-1-07-mb.meta.html http://walrus.wr.usgs.gov/infobank/p/p107mb/html/p-1-07-mb.meta.html

For an online PDF version of this report, please see:

http://pubs.usgs.gov/of/2007/1270/

For more information on the U.S. Geological Survey Western Region's Coastal and Marine Geology Team, please see:

http://walrus.wr.usgs.gov/

For data files described in this report, please contact:

Dr. Curt D. Storlazzi (Project Chief)

USGS Pacific Science Center

400 Natural Bridges Drive

Santa Cruz, CA 95060

cstorlazzi@usgs.gov

\section{SUGGESTED CITATION}

C.D. Storlazzi, Barnard, P.L., Collins, B.D., Finlayson, D.P., Golden, N.E., Hatcher, G.A., Kayen, R.E., and Ruggiero, Peter, 2007, High-resolution topographic, bathymetric, and oceanographic data for the Pleasure Point area, Santa Cruz County, California; 2005-2007: U.S. Geological Survey OpenFile Report 2007-1270, 28 p. 


\section{INTRODUCTION}

The County of Santa Cruz Department of Public Works and the County of Santa Cruz Redevelopment Agency requested the U.S. Geological Survey (USGS) Western Coastal and Marine Geology Team (WCMG) to provide baseline geologic and oceanographic information on the coast and inner shelf at Pleasure Point, Santa Cruz County, California. The rationale for this proposed work is a need to better understand the environmental consequences of a proposed bluff stabilization project on the beach, the nearshore and the surf at Pleasure Point, Santa Cruz County, California (FIG. 1). To meet these information needs, the USGS-WCMG Team collected baseline scientific information on the morphology and waves at Pleasure Point. This study provided high-resolution topography of the coastal bluffs and bathymetry of the inner shelf off East Cliff Drive between $32^{\text {nd }}$ Avenue and $41^{\text {st }}$ Avenue. The spatial and temporal variation in waves and their breaking patterns at the study site were documented. Although this project did not actively investigate the impacts of the proposed bluff stabilization project, these data provide the baseline information required for future studies directed toward predicting the impacts of stabilization on the sea cliffs, beach and nearshore sediment profiles, natural rock reef structures, and offshore habitats and resources. They also provide a basis for calculating potential changes to wave transformations into the shore at Pleasure Point.

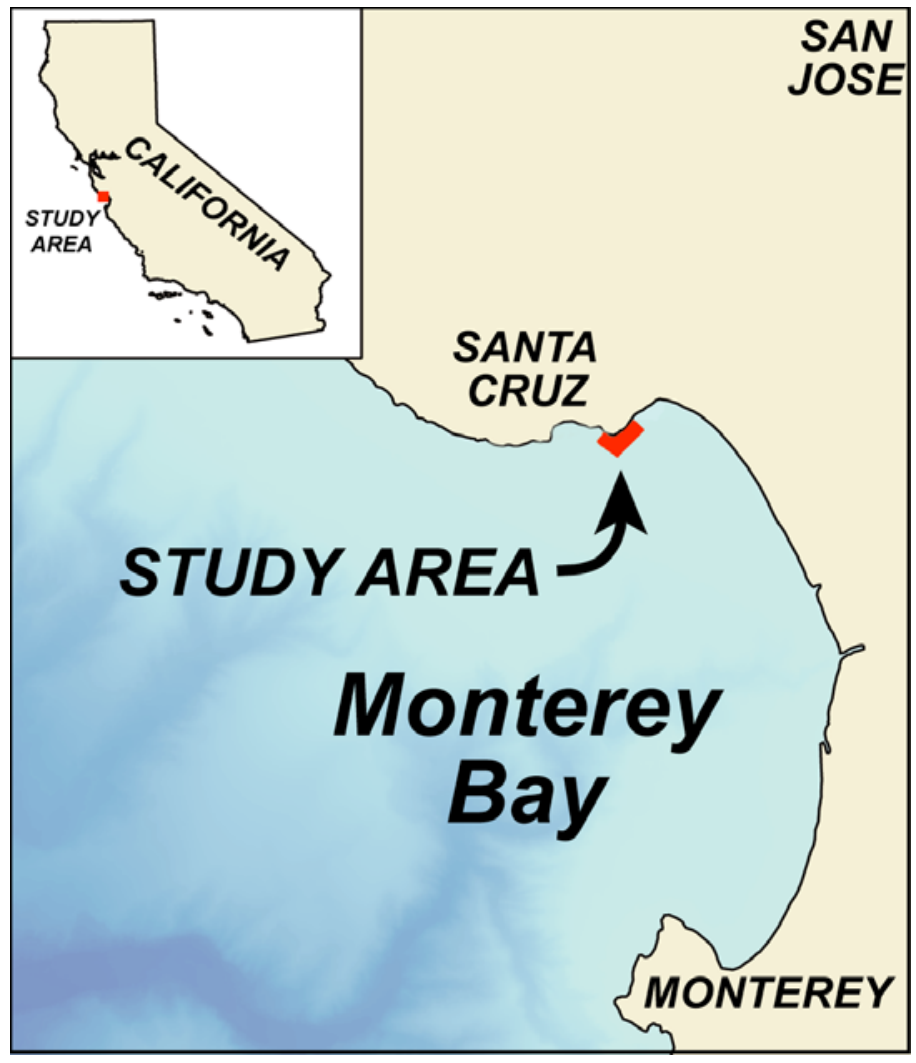

FIGURE 1. Location of the study area.

\section{Background}

The Pleasure Point area in northern Monterey Bay is a complex coastal setting of sea cliffs and small pocket beaches that are influenced by a variable wave climate due to its south-facing 
orientation. Large winter swells typically arrive from the northwest and west; however, this area also experiences un-refracted waves out of the southwest during the summer. Spatially and temporally variable wave conditions and the complex, shallow, rocky seafloor at this site have restricted comprehensive field surveys in the past. Recent innovations in field techniques and equipment, as well as remote-sensing techniques, now make it possible to perform a detailed analysis of the morphology and physical processes operating on this type of complex coastline. Understanding the morphology and waves off Pleasure Point is important because it is part of the Monterey Bay National Marine Sanctuary and the seacliffs in this area protect infrastructure (road, water and sewage lines) that is crucial to Santa Cruz County. Continuing erosion has threatened this infrastructure, and thus it has become increasingly important to provide scientific data that will allow the various government agencies involved with the area to make the best informed management decisions.

\section{Project Description and Objectives:}

The USGS Pleasure Point Study provided baseline information for future studies of impacts of the proposed East Cliff Drive Stabilization Project. An integrated study to document both the coastal and nearshore morphology and the spatial and temporal variation in waves at the study site was conducted. These data were collected by means of three-dimensional beach and seacliff mapping, nearshore bathymetric surveys, video monitoring and oceanographic instrumentation. All of the data were collected to USGS standards and thus are the foundation for any future surveys conducted to investigate change in morphology or processes at the study site. These surveys, initiated in October, 2005, and extending through May, 2007, were required to determine future long-term impacts by the proposed bluff stabilization project on the study area.

\section{Task 1 - Mapping}

High-resolution maps of the Pleasure Point area were compiled for both the terrestrial and subaqeous parts of the study area from a combination of historical and newly collected data. The morphology of the seacliffs was documented using historic airborne lidar (Light Detection and Ranging) data and terrestrial lidar data. The bathymetry of the inner shelf was collected using single-beam fathometers and an interferometric side-scan swath bathymetric sonar. This topographic and bathymetric data will provide the baseline data for any future survey efforts trying to detect change and a valuable resource for management decisions for Pleasure Point. Furthermore, these data will provide the necessary topographic and bathymetric boundary information for any future numerical modeling efforts attempting to predict coastal erosion or changes to wave breaking patterns under different future scenarios (climate change, sea level rise, seawall construction, etc.).

\section{Subtask 1.1 - Historical Data}

Historic airborne scanning lidar survey data provided topographical coverage for determining regional shoreline position and seacliff morphology for comparison with the higher-resolution survey work described here.

\section{Subtask 1.2 - Terrestrial Lidar}

The terrestrial portion of the study area, from the top of the seacliffs down to the beach and intertidal bedrock reefs were surveyed at very high resolution (typical point to point spacing of several centimeters) using a terrestrial lidar scanner. Because ground-based lidar scanning can be performed with a horizontal look angle, not only is the cliff topography point density much higher that from an airborne platform, but geologic features such as sea caves and wave cut notches can also be captured. The terrestrial lidar collected along the Pleasure Point study area 
was used to create a high-resolution digital elevation model of the terrestrial portion of the study area. The fieldwork component of this subtask was conducted from the fall of 2005 through the winter of 2006.

\section{Subtask 1.3 - Shallow Nearshore Bathymetry}

To map the bathymetry in very shallow water (depths $<5 \mathrm{~m} / 16 \mathrm{ft}$ ) where larger traditional survey vessels cannot operate, the single-beam USGS Coastal Profiling System (CPS) with real-time kinematic differential global positioning system (RTK-DGPS) and echo sounder equipment was employed to collect single beam bathymetry over the shallow nearshore off Pleasure Point. The fieldwork component of this subtask was conducted in the fall of 2005.

\section{Subtask 1.4-Deeper Nearshore Bathymetry}

An interferometric side-scan swath bathymetric sonar survey was run offshore Pleasure Point, the first ever high-resolution swath bathymetric survey in this region, to complement the shallower single-beam CPS survey discussed above. This provided broad spatial coverage from approximately $0.5 \mathrm{~km}$ offshore into water depths of 3-4 $\mathrm{m}$; the shallower portion of the swath bathymetry thus overlapped the deeper portion of the CPS survey. The fieldwork component of this subtask was conducted in the fall of 2005.

\section{Task 2 - Wave Characterization}

The spatial and temporal variation in the incoming waves and the resulting breaking wave patterns at Pleasure Point area were documented from a combination of in situ instrumentation and remote sensing techniques. The information on the incident wave and current field at the study site was collected by way of oceanographic instrumentation deployed just offshore of the coast at a depth of $14 \mathrm{~m}$. Wave breaking patterns were documented using a web-based camera system deployed at a private residence on East Cliff Drive. These data will provide the baseline data for any future survey efforts trying to detect change and be a valuable resource as management decisions for Pleasure Point are being made. Furthermore, these data will provide the necessary incident forcing parameter boundary information for any future numerical modeling efforts attempting to predict coastal erosion or changes to wave breaking patterns under different future scenarios (climate change, sea level rise, seawall construction, etc.).

\section{Subtask 2.1 - Temporal Variation in Currents and the Incident Wave Field}

An acoustic Doppler current profiler (ADCP) was deployed for 12 months offshore Pleasure Point to document the range of tide, wave and current conditions observed over a single year. This sensor will make it possible to determine the link between the offshore wave conditions measured by the deep-water NDBC Monterey Bay \#46042 (NDBC, 2007) directional wave buoy and the resulting wave breaking patterns at Pleasure Point imaged by the web-based camera system. The fieldwork component of this subtask was initiated in the late spring of 2006 and data were collected through the late spring of 2007.

\section{Subtask 2.2 - Spatial and Temporal Variation in Breaking Wave Patterns}

A digital camera system was installed to document the patterns of breaking waves across the study area in real-time. This video monitoring made it possible to track wave breaking patterns, rip-channel development and potentially infer rock reef and/or sand-bar location(s) under a range of wave and tide conditions. These data can then be compared to offshore deep-water offshore wave conditions measured by the deep-water National Data Buoy Center (NDBC) Monterey Bay \#46042 (NDBC, 2007) directional wave buoy and the ADCP discussed above. The fieldwork 
component of this subtask was initiated in late spring 2006 and data were collected through the late spring of 2007.

\section{DATA ACQUISITION}

\section{Subtask 1.1 - Historical Data}

The Airborne Topographic Mapper (ATM) lidar data were collected in partnership with the National Oceanic and Atmospheric Administration (NOAA) Coastal Services Center, the NASA Wallops Flight Facility, the USGS Center for Coastal and Regional Marine Geology, and the NOAA Aircraft Operations Center. The ATM can survey beach topography along hundreds of kilometers of coast in a single day with data densities that cannot be achieved with traditional survey technologies (FIGURE 2). For each pass along the coast, the ATM lidar scanned a 375-m wide swath along the aircraft flight line. For most of the study area, four overlapping passes were flown yielding a typical surveyed swath approximately 700-m wide with laser spot elevations every $3 \mathrm{~m}^{2}$. The aircraft pitch, roll, and heading were obtained with an inertial navigation system and the positioning of the aircraft was determined using kinematic Global Positioning System (GPS) techniques. The twin-engine turboprop aircraft, a De Havilland Twin Otter, was provided and operated by NOAA's Aircraft Operations Center, McDill Air Force Base, Tampa, FL. The local topography of the area was derived from ATM data acquired on 04/17/1998 and 04/18/1998 following the intense storms of the 1997-1998 winter; these data were obtained from the Coastal Services Center (2006) website. More than 918,100 data points were acquired during the two days of surveying, extending from the water line up to the top of the seacliffs and some distance landward. See http://coastal.er.usgs.gov/lidar/AGU fall98/for more information.

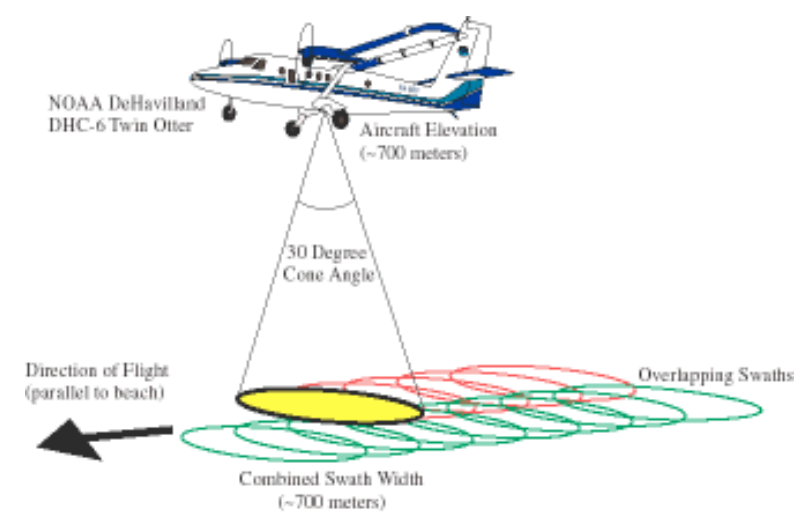

FIGURE 2. Schematic showing the elliptical scan pattern of the ATM. Image from http://coastal.er.usgs.gov/lidar/AGU_fall98/

\section{Subtask 1.2-Terrestrial Lidar}

Terrestrial lidar data were collected of the seacliffs, beaches, and intertidal bedrock reef platform areas. Terrestrial lidar is the newest and most accurate technology being used to map and monitor coastal bluff stability (Collins and Sitar, 2004, 2005). The data collection technique consists of sending and receiving laser pulses to build a point file of three-dimensional coordinates of virtually any reflective surface. The time of travel for a single pulse reflection is measured along a known trajectory such that the distance from the laser and consequently the exact location of a point of interest is computed. The USGS WCMG terrestrial lidar system 
consists of a Riegl Z210 instrument mounted on a tripod platform (FIGURE 3). The instrument captures data at approximately 8,000 points per second with a typical range of 100's of $\mathrm{m}$ and at an accuracy of $25 \mathrm{~mm}$ for each point. Additional specifications of the unit are provided in APPENDIX 1.

Data collection consisted of setting up the instrument with the best possible field of view for each location along and above the seacliffs (FIGURE 4). The unit was then moved to the next scan location, which was determined by the required data density and the relative irregularity of the seacliffs (i.e. cliffs with many caves or inlets require more scans to capture all aspects of the features). In October, 2005, data were collected from the seacliff crest during high tide, capturing topographic data of the crest area to some $50 \mathrm{~m}$ back from the cliff edge along with some seacliff data captured from key vantage points near the edge. In January, 2006, data were collected from the intertidal bedrock platform during a period of extremely low tides. This field effort collected data of the seacliff, beach, and intertidal reef. In February, 2006, data were collected of a section of cliff immediately adjacent to Pleasure Point (Opal Cliffs area) again, at a low tide from the intertidal bench. Additional data were collected of this area in January, 2007, to improve final data accuracy.

In total, scans from 54 individual locations were performed, collecting a total of 38.1 million points of ground topographic data and an additional 6.6 million points of cultural features such as houses, signs, fences, etc. Several post-processing steps were necessary. The data were filtered to remove non-terrain objects (people, cars, etc.). Adjacent scans were registered to one another through a local fit of overlapping points, and georeferenced to geodetic coordinates through the use of control points visible in the scan data and locatable in the field. Field survey of the control points was performed in June, 2006, and consisted of a post-processed differential

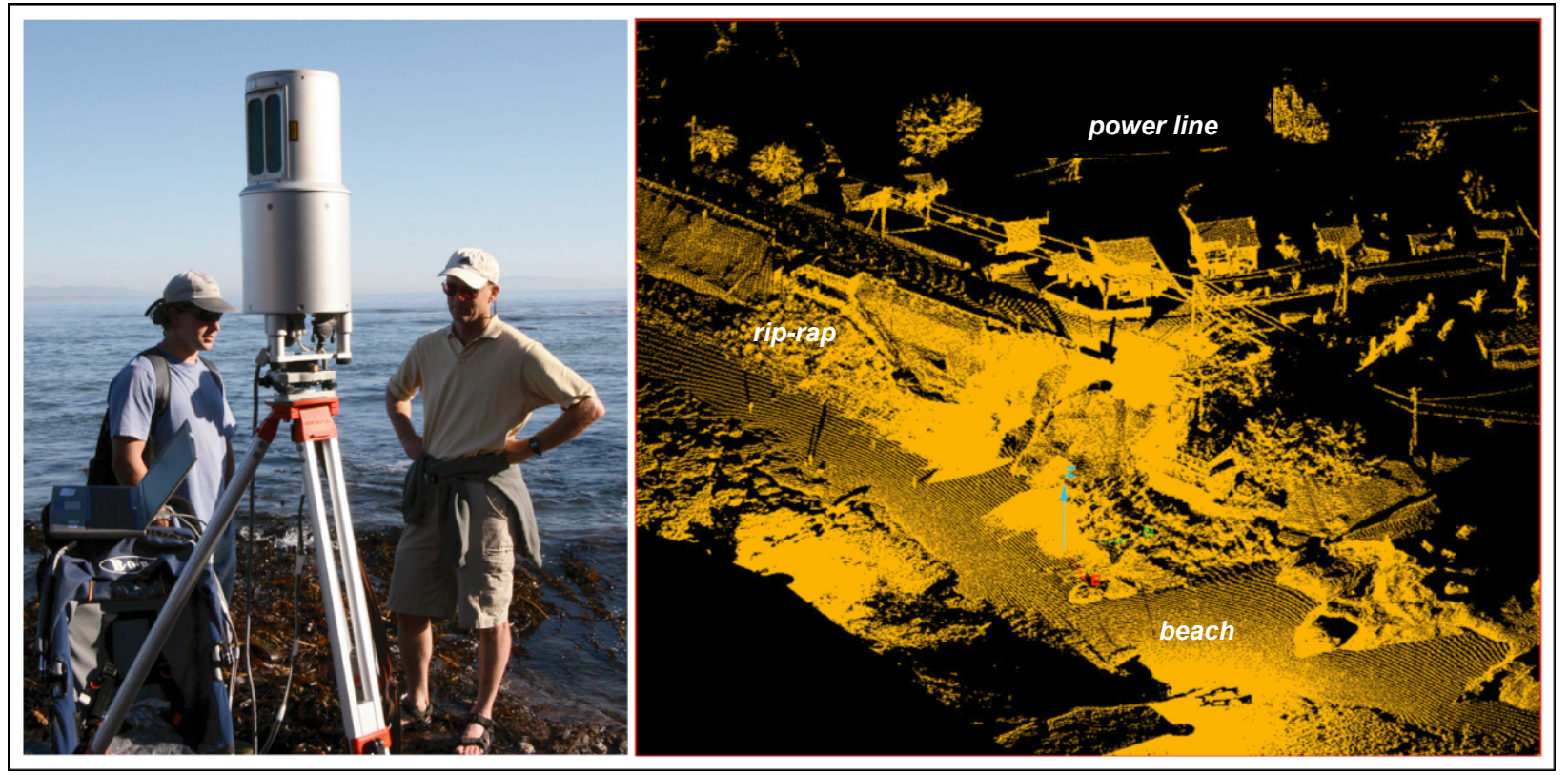

FIGURE 3: Topographic lidar data acquisition and an example scan. LEFT: Photograph of the lidar scanner during data acquisition on the intertidal bedrock reefs at low tide. Laser pulses exit and enter the scanner through the two vertical windows on the panning unit; the data acquisition computer is in the baby jogging stroller. RIGHT: Individual scan taken just east of the stairwell at $36^{\text {th }}$ Avenue. Houses, rip-rap, people and even individual power lines are clearly identifiable in the data. 
GPS survey on 30 control points. In some cases, a differential RTK GPS unit was placed directly on the lidar instrument to achieve an increased level of accuracy. The georeferenced points were then filtered to obtain a consistently dense data set for surface modeling. The final digital elevation model (DEM) was created from a point set with a typical point-to-point spacing of 20 $\mathrm{cm}$.

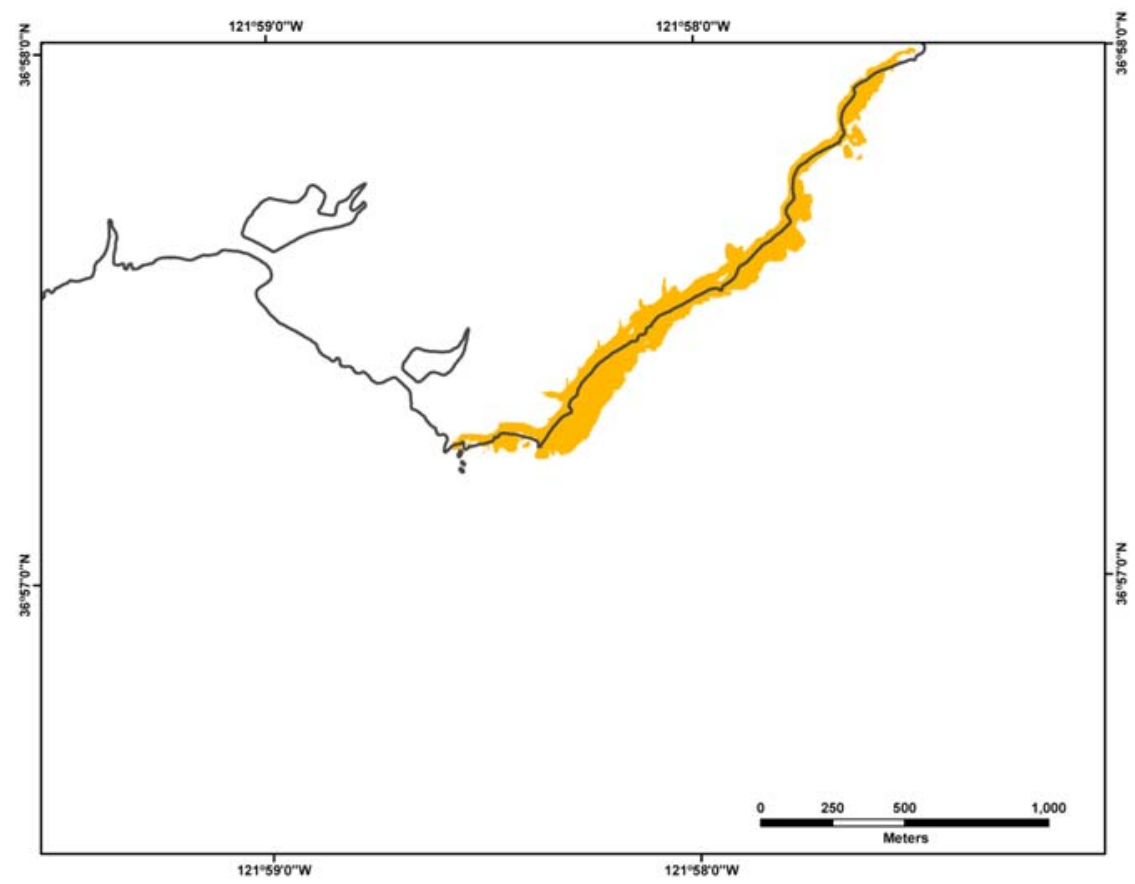

FIGURE 4: Region of topographic lidar data coverage in the study area.

\section{Subtask 1.3 - Shallow Nearshore Bathymetry}

The Coastal Profiling System (CPS), a hydrographic surveying system mounted on a Personal Watercraft (PWC), was used to collect shallow-water bathymetric data off Pleasure Point (FIGURE 5). Combining the high accuracy positioning of Differential Global Position System (DGPS), the efficiency of an acoustic echo sounder, and the mobility of a personal watercraft, the CPS provides a fast and accurate method to achieve sub-decimeter accuracy; reasonable variations in water temperature and salinity (not measured), however, can affect depth estimates by as much as $3 \%$ of the water depth. The CPS collected data at $5 \mathrm{~Hz}$ and, while traveling at $3 \mathrm{~m} / \mathrm{s}$, generated a depth sounding every $0.6 \mathrm{~m}$ along the sea floor. These data were collected assuming a sound velocity of $1500 \mathrm{~m} / \mathrm{s}$. A more complete discussion of the CPS can be found in MacMahan (2001), Ruggiero et al. (2005) and APPENDIX 2.

Twenty-five shore-normal and 23 shore-parallel track lines were collected (FIGURE 6). Due to heavy kelp coverage in some locations and RTK-GPS problems, data coverage was sometimes intermittent. In general, however, data quality was extremely high and more than $90 \%$ of the planned study area was covered. Data was collected into water depths less than $1 \mathrm{~m}$ and out into depths of more than $12 \mathrm{~m}$.

To eliminate bed data or data outliers, each individual transect was examined, typically using a Perl script and HYPACK software (the program used to collect the data), to detect and remove any data points collected when the GPS receiver was not initialized in kinematic mode. This 


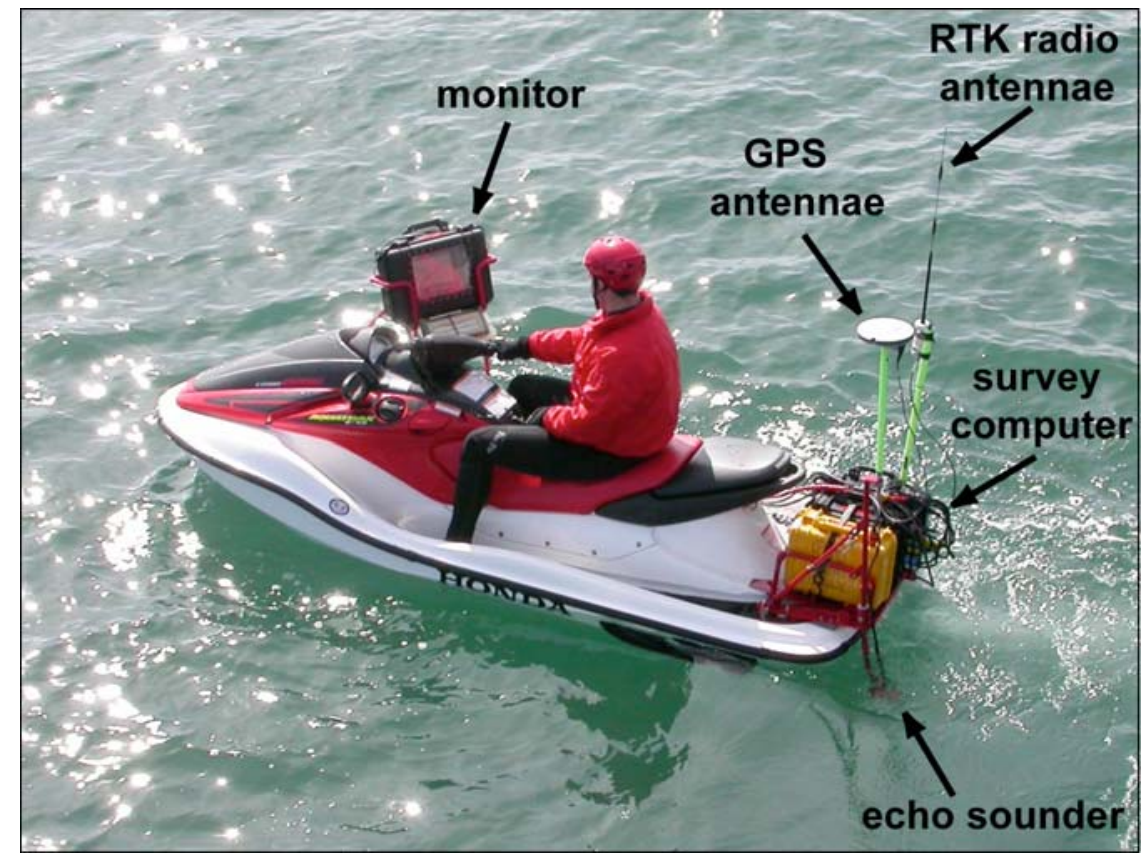

FIGURE 5. A Coastal Profiling System acquiring data. The black waterproof case by the handlebars holds the navigation display and quick keyboard, the white circular GPS antenna and black RTK whip antenna are mounted directly over the fathometer on a pole attached to the stern, and the waterproof cases on the stern hold the batteries and electronics for the computer, GPS and fathometers.

script also eliminated any obvious outliers from the raw files that are either shallower than the echo sounder blanking interval or deeper than a user defined cutoff value. The individual files were then exported in UTM Zone 10 Easting, Northing, Elevation ASCII triplets with one data file per transect. A smoothing operation was then performed using a median filter on the z-

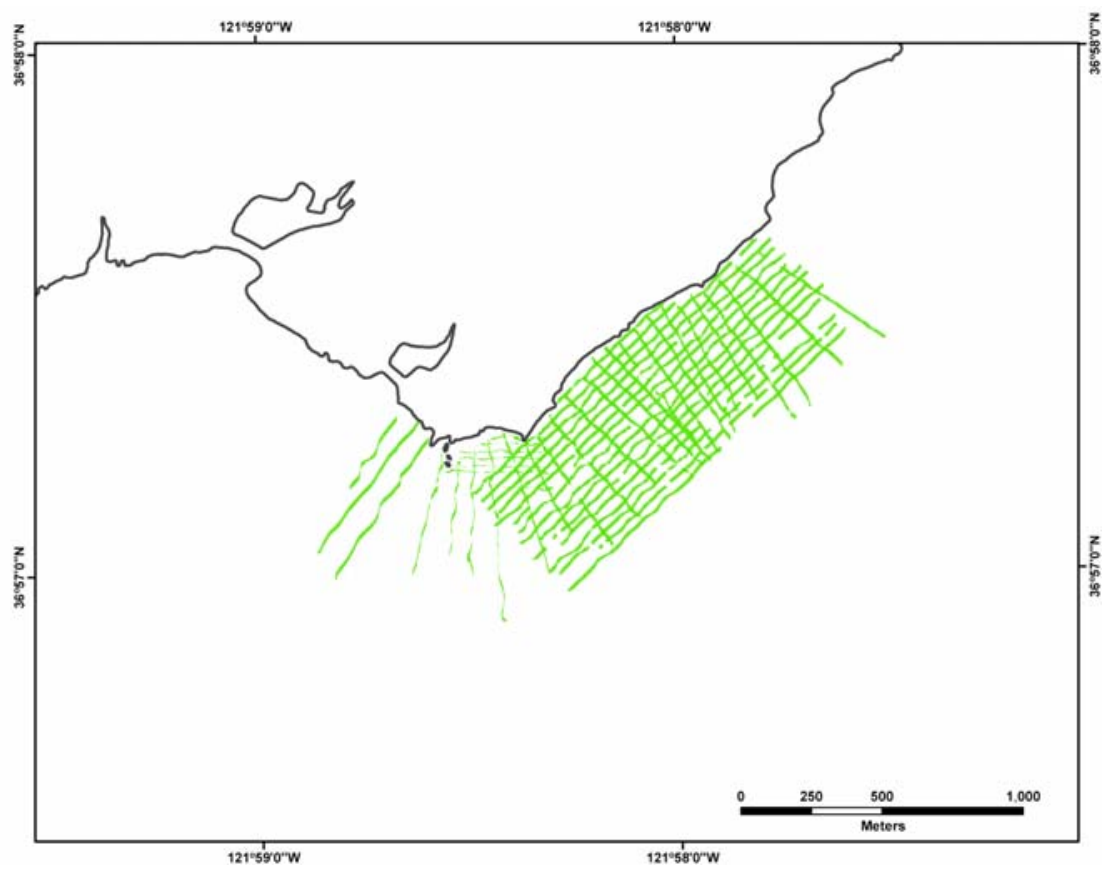

FIGURE 6. Coastal Profiling System survey track lines in the study area. 
coordinate in the alongline direction to reduce high frequency fluctuations. Varying window sizes were used to obtain a smooth profile while maintaining the integrity of the actual data points. In total, more than 103,033 data points were acquired during the one day of surveying, extending from mean sea level down to water depths just less than $12 \mathrm{~m}$.

\section{Subtask 1.4-Deeper Nearshore Bathymetry}

The deeper nearshore bathymetric survey was conducted aboard the $R / V$ Paragon, a $10 \mathrm{~m}(32 \mathrm{ft}$ ) Radon-style, twin outboard vessel owned and operated by the University of California, Santa Cruz (FIGURE 7). A temporary data processing shed was placed on the fantail to protect the acquisition computers and operator from the weather, and the SEA SWATHplus interferometric side-scan swath bathymetric sonar was pole-mounted to the starboard gunnel (FIGURE 8). SWATHplus is a $234 \mathrm{kHz}$ side scan system that simultaneously collects bathymetry and backscatter information using amplitude and phase difference information from multiple transducers (APPENDIX 3).

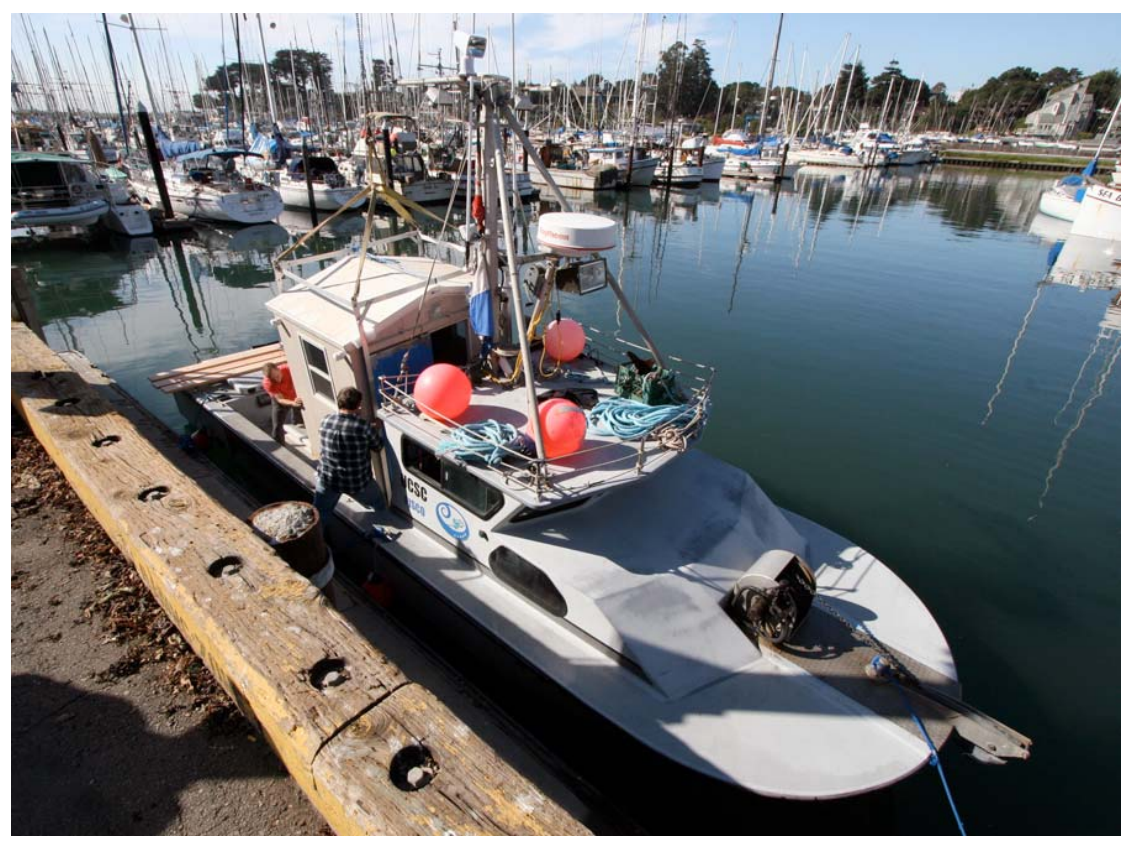

FIGURE 7. Loading the temporary data processing shed onto the fantail of the R/V Paragon.

No direct vertical control was available in the study area during the survey. Instead, vertical control was established using observed water levels from the National Ocean Service (NOS, 2007) Tide Station \#9413450 located in Monterey Harbor (36³6.3' N, $121^{\circ} 53.3^{\prime}$ W). NOAA has established tidal harmonics for Santa Cruz that deviate slightly from the Monterey Bay reference station, however, the maximum deviation between the reference station and Santa Cruz is approximately $10 \mathrm{~cm}$ at full tide range. This difference is the same as the theoretical maximum precision of the SWATHplus system $(\sim 10 \mathrm{~cm})$ under ideal conditions, so the Monterey Bay observed tides were used without adjustment during post processing.

The time series of observed water levels at Monterey Bay was downloaded from the NOS web site (NOS, 2007) prior to post processing. These data were then entered into the SEA Swath Processor acquisition software to establish Mean Lower Low Water (MLLW) as the vertical datum of the survey. This survey can be converted to other vertical datums (such as NAVD 88) by 


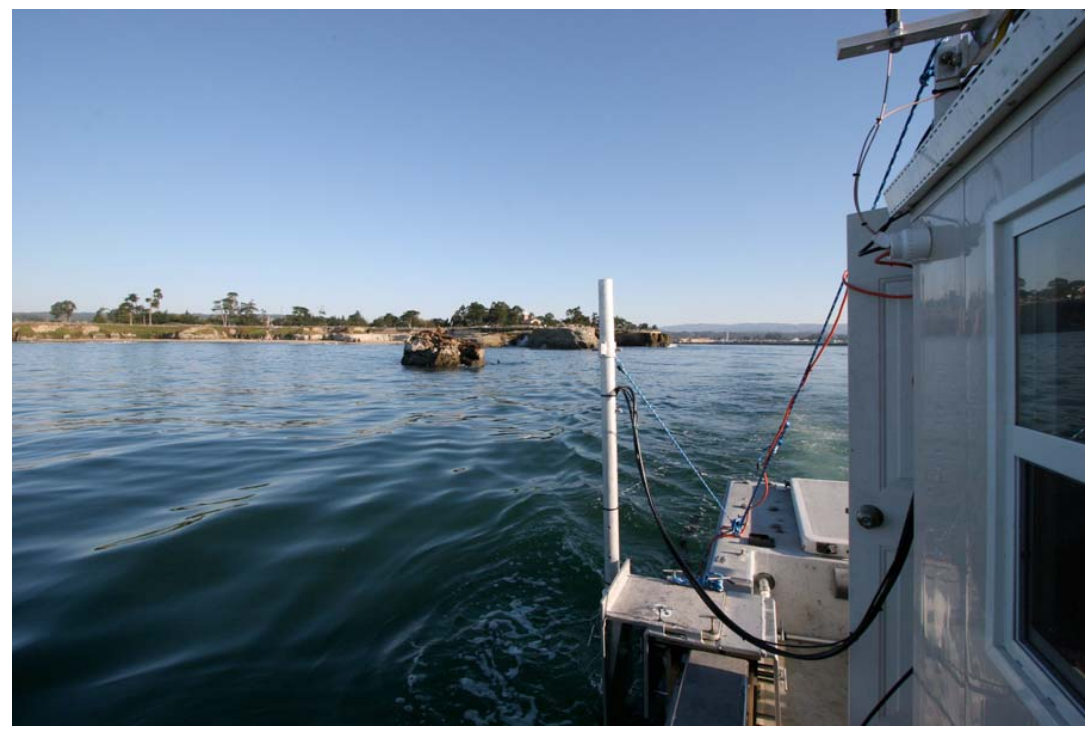

FIGURE 8. Underway view of the starboard gunnel of the R/V Paragon showing the pole mount used to deploy the transducers.

referring to the tidal benchmark sheet for NOS Station 9413450 (Epoch 1983-2001). For reference, NAVD 88 is $0.04 \mathrm{~cm}$ below MLLW at the benchmark.

Sound velocity profiles (SVP) for the survey were estimated by manually dropping a sound velocity profiler. SVPs were collected at the beginning of each day and periodically during the day as dictated by the environment. Overall, 11 SVPs were collected over five survey days. In

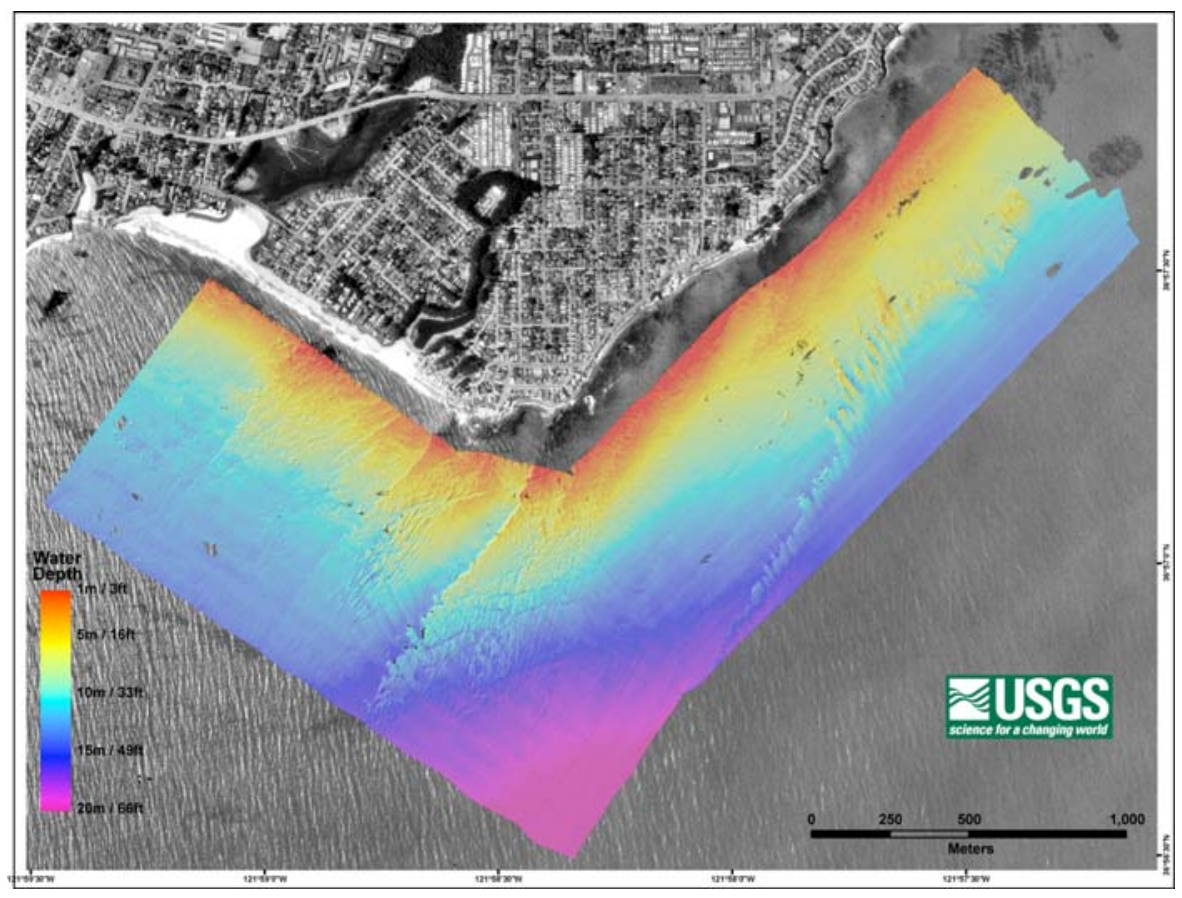

FIGURE 9: Color-coded swath bathymetry of the study area overlaid on a 2005 black and white digital orthophotograph. 
total, more than 3,242,199 soundings were acquired during this survey, extending from water depths just less $2 \mathrm{~m}$ to more than $21 \mathrm{~m}$ (FIGURE 9).

\section{Subtask 2.1 - Temporal Variation in Currents and the Incident Wave Field}

An upward-looking 1-MHz Nortek AWAC ADCP was deployed for 12 months offshore Pleasure Point to document the range of wave energy conditions observed over a year. The AWAC (FIGURE 10, TABLE 1) collected a vertical profile of current velocity and acoustic backscatter (a proxy for suspended sediment) through the water column, along with water depth and temperature data, once a second for $6 \mathrm{~min}$. These 3,600 samples were averaged to produce one sample per parameter every 20 min (APPENDIX 4). Every hour, the AWAC collected current and pressure (water depth) data twice a second for $8.5 \mathrm{~min}$; these data were then used to compute wave height, wave period, wave direction, and directional wave energy spectra once an hour. This sensor will make it possible to determine the link between the offshore wave conditions measured by the deep-water NDBC Monterey Bay (\#46042) directional wave buoy and the resulting wave breaking patterns at Pleasure Point imaged by the web-based camera system (see below). These data, in conjunction with the proposed nearshore bathymetry, are crucial if accurate modeling of waves in the study area under a range of scenarios (engineering, climate, etc.) is desired by resource managers in the future. The fieldwork component of this subtask was initiated in the late spring of 2006 and data were collected through the late spring of 2007.

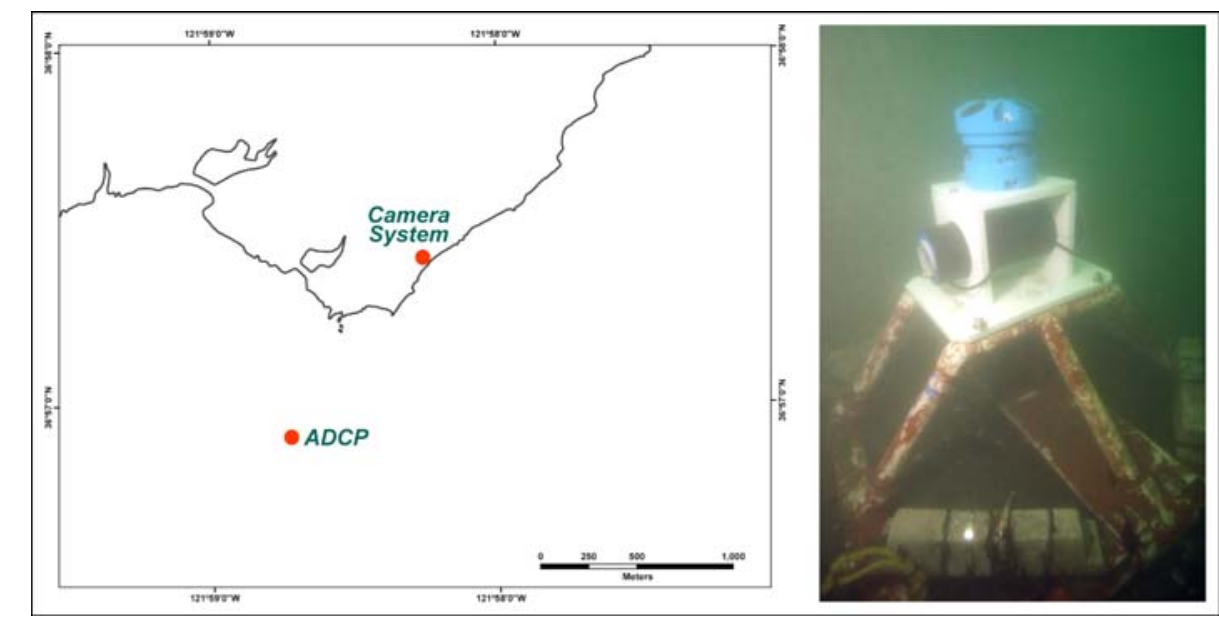

FIGURE 10: Location and image of the AWAC deployed off Pleasure Point from 05/2006-06/2007. LEFT: Location of the AWAC and the camera system relative to the shoreline. RIGHT: Underwater photograph of the AWAC deployed at a depth of $13 \mathrm{~m}$.

TABLE 1: AWAC deployment log.

\begin{tabular}{ccccc}
\hline \hline Deployment & $\begin{array}{c}\text { Deployment Date } \\
{[\mathrm{MM} / \mathrm{DD} / \mathrm{YYYY}]}\end{array}$ & $\begin{array}{c}\text { Recovery Date } \\
{[\mathrm{MM} / \mathrm{DD} / \text { /YYY] }}\end{array}$ & $\begin{array}{c}\text { Current } \\
\text { Measurements }\end{array}$ & $\begin{array}{c}\text { Wave } \\
\text { Measurements }\end{array}$ \\
\hline 1 & $05 / 19 / 2006$ & $08 / 21 / 2006$ & 6769 & 2255 \\
2 & $08 / 24 / 2006$ & $11 / 29 / 2006$ & 6985 & 2327 \\
3 & $12 / 04 / 2007$ & $03 / 12 / 2007$ & 7059 & 2352 \\
4 & $03 / 14 / 2007$ & $06 / 05 / 2007$ & 5981 & 1993 \\
\hline \hline
\end{tabular}

Overall, 8,927 wave bursts ( $>400,000$ individual waves) and 26,794 current profiles were collected (FIGURE 11). The minimum, mean \pm one standard deviation wave heights during the period were 
$0.34 \mathrm{~m}, 0.92 \pm 0.27 \mathrm{~m}$, and $5.10 \mathrm{~m}$, respectively. The minimum, mean \pm one standard deviation, and maximum wave periods during the study period were $3.2 \mathrm{~s}, 12.3 \pm 2.1 \mathrm{~s}$, and $23.8 \mathrm{~s}$, respectively; the mean \pm one standard deviation wave direction during the study period was $211.3 \pm 8.6^{\circ}$, with a range of $182.7^{\circ}-240.6^{\circ}$.
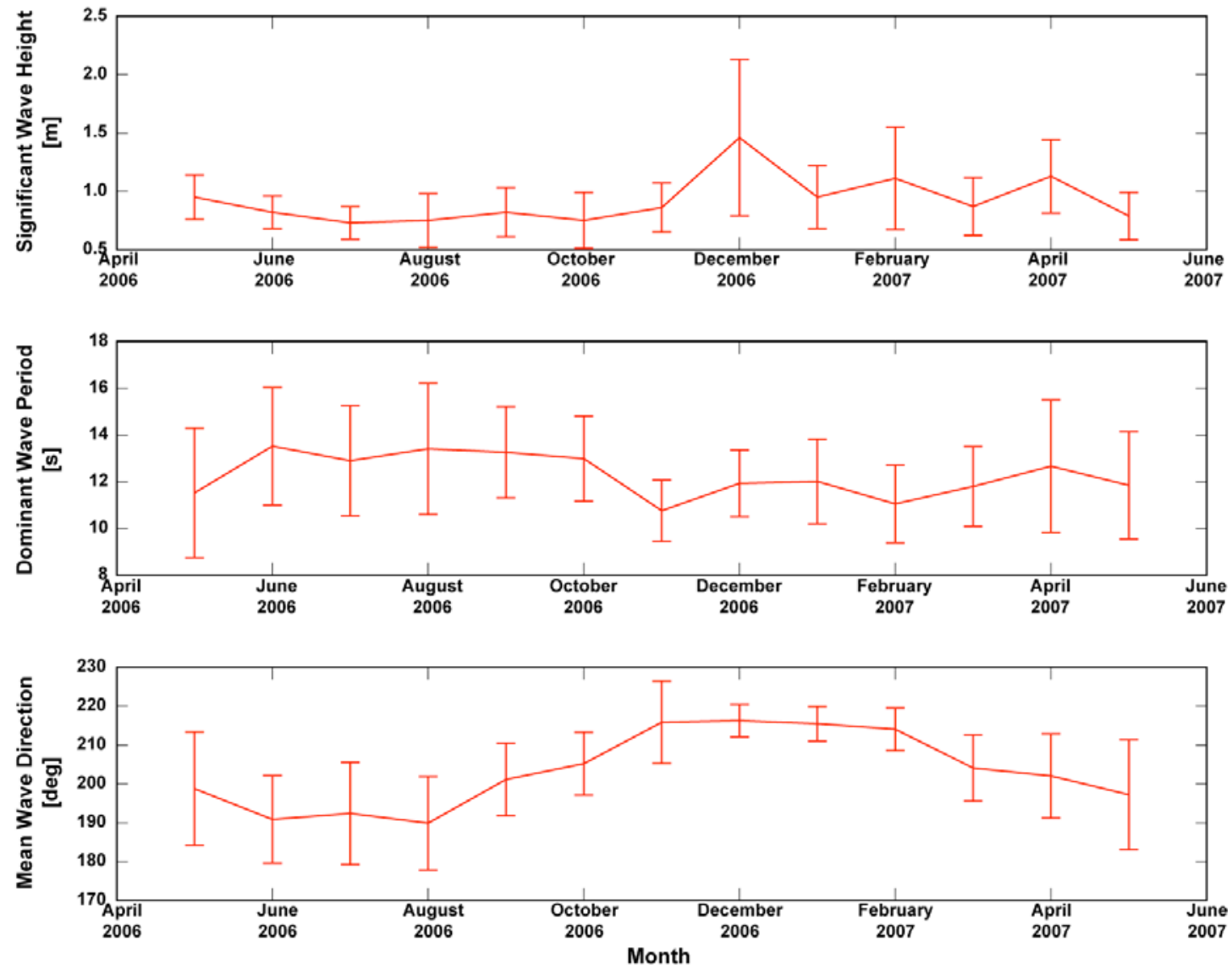

FIGURE 11: Variation in the incident wave field during the periods of data acquisition. TOP: Significant wave height, in meters. MIDDLE: Dominant wave period, in seconds. BOTTOM: mean wave direction, in degrees true. The lines denote the monthly mean values while the error bars denote \pm one standard deviation.

\section{Subtask 2.2 - Spatial and Temporal Variation in Breaking Wave Patterns}

The web-based camera system was comprised of an analog video camera and a digital still camera, housed in a single pan and tilt unit (FIGURE 12), and linked to a computer and DSL connection such that the camera could be controlled remotely from the USGS office in Santa Cruz (APPENDIX 5). Data from various sections of the study area were therefore collected (TABLE 2). Since these data were posted automatically to the web, the Santa Cruz County Redevelopment Agency, Santa Cruz County Department of Public Works and the California Department of Boating and Waterways and other agencies were able to access the data in real time. The video monitoring makes it possible to track wave breaking patterns (FIGURE 13-15), rip channel development and potentially infer sand-bar location(s) under a range of wave conditions. When considering the cultural usage of the Pleasure Point area, these data could also be used to document number of individuals in the imagery, either for (a) simply documenting the number of people who actually surf, or (b) for determining carrying capacity for any new infrastructure (new 
bathrooms, stairs, etc). The digital imagery can be compared to offshore deep-water offshore wave conditions measured by the deep-water NDBC Monterey Bay directional wave buoy and

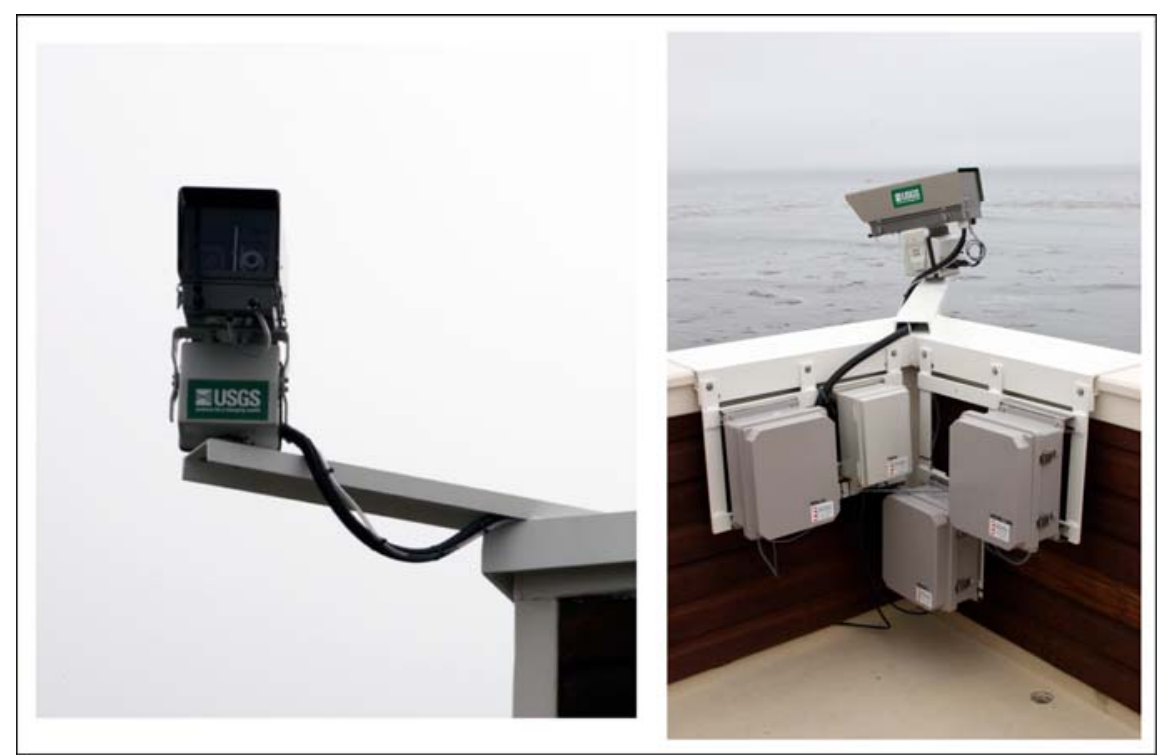

FIGURE 12: Components of the digital imaging system. LEFT: The front of the camera housing, with the Sony Block video camera on the left and the Olympus 8 mega-pixel still camera on the right. RIGHT: Weatherproof enclosures containing the power supply, data acquisition computer, pan/tilt controller, DSL modem and windshield washer tank. See FIGURE 10 for location information.

the USGS ADCP measurements to understand the relationships between the incident wave field and breaking patterns in the field area. The fieldwork component of this subtask was initiated in the late spring of 2006 and data were collected through the late spring of 2007. Overall, 30,317 digital stills and 12,744 digital video time averages were collected (TABLE 2).

TABLE 2: Digital imaging system data acquisition statistics.

\begin{tabular}{lccc}
\hline \hline Scene & Type & Description & Images \\
\hline p1 & Still & Hook & 3,027 \\
p2 & Still & 38th Avenue & 3,027 \\
p3 & Still & Jack's & 3,027 \\
p4 & Still & Pleasure Point 3rd peak & 3,027 \\
p5 & Still & Pleasure Point 1st peak & 3,027 \\
p10 & Still & Hook zoom & 1,326 \\
p11 & Still & 38th Avenue zoom & 1,355 \\
p20 & Still & Pleasure Point 3rd peak zoom & 1,355 \\
p21 & Still & Pleasure Point 1st peak zoom & 1,398 \\
d12 & Still & Pleasure Point composite & 3,443 \\
d14 & Still & Hook-38th Avenue composite & 3,427 \\
d38 & Still & Study Area panoramic & 2,878 \\
s5 & Video & Pleasure Point 1st peak & 3,257 \\
s18 & Video & Pleasure Point 3rd peak & 3,173 \\
s23 & Video & 38th Avenue-Jack's & 3,166 \\
s32 & Video & Hook-38th Avenue & 3,148 \\
& & Still & 30,317 \\
Total & & Video & 12,744 \\
Total & & & \\
\hline
\end{tabular}




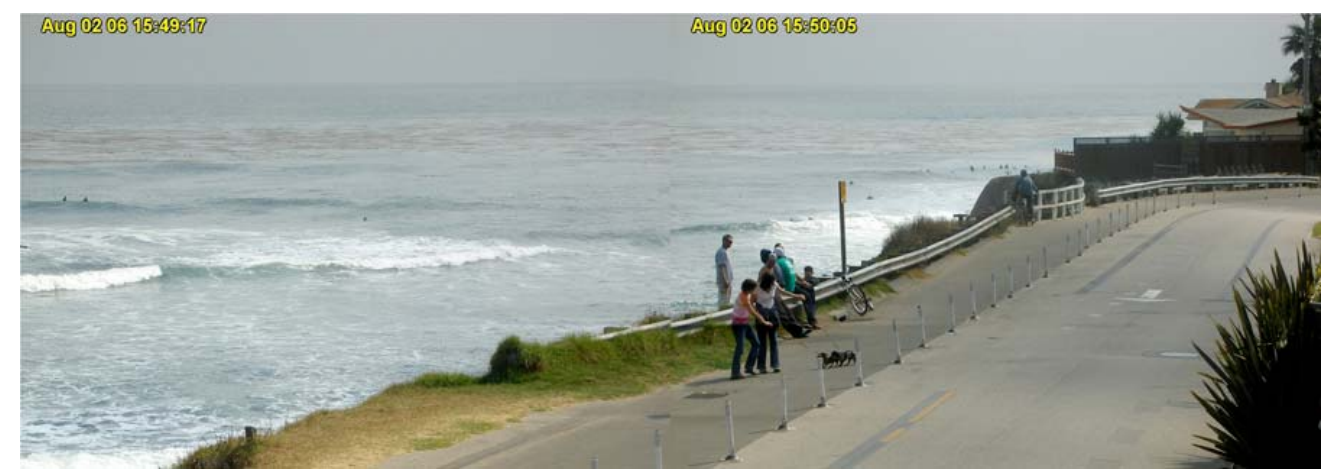

FIGURE 13. Two merged 8 mega-pixel digital still photographs taken of the Pleasure Point surf breaks.

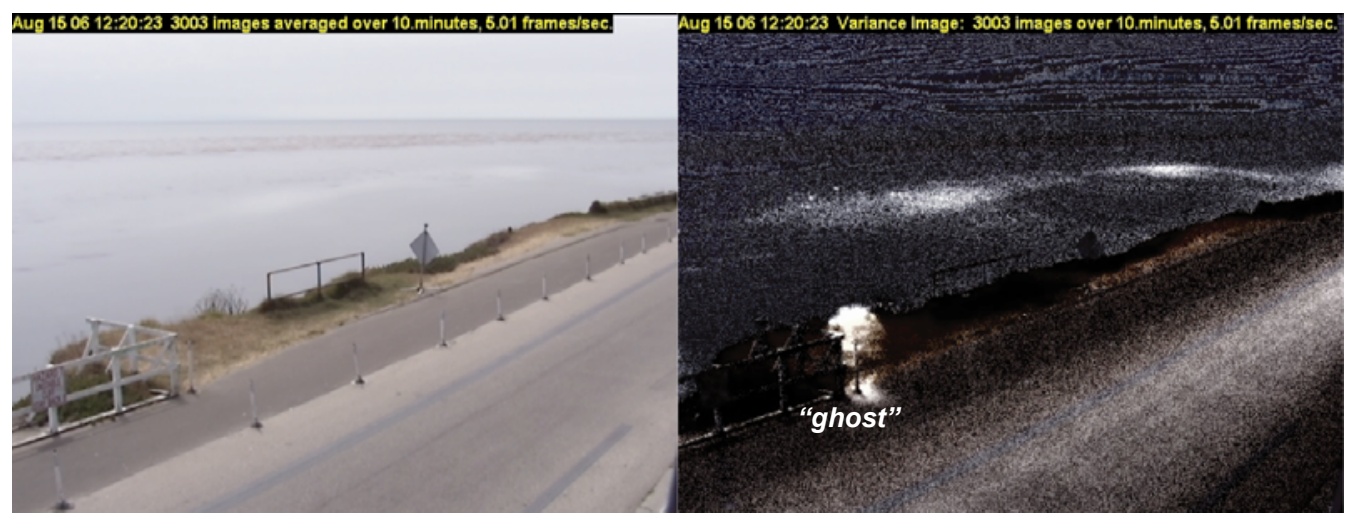

FIGURE 14: Video camera data from a period with small $(0.5 \mathrm{~m})$ waves (08/15/2006). LEFT: Average of more than 3,000 images taken at $5 \mathrm{~Hz}$. RIGHT: Variance of more than 3,000 images taken at $5 \mathrm{~Hz}$. Note that, due to the sun angle, it is difficult to delineate the region of wave breaking and whitewater (wave bores); however, these areas are easily identifiable as white regions in the variance data. "Ghosts" in the imagery are where people were in the field of view for a part of the 10 min period of data acquisition.

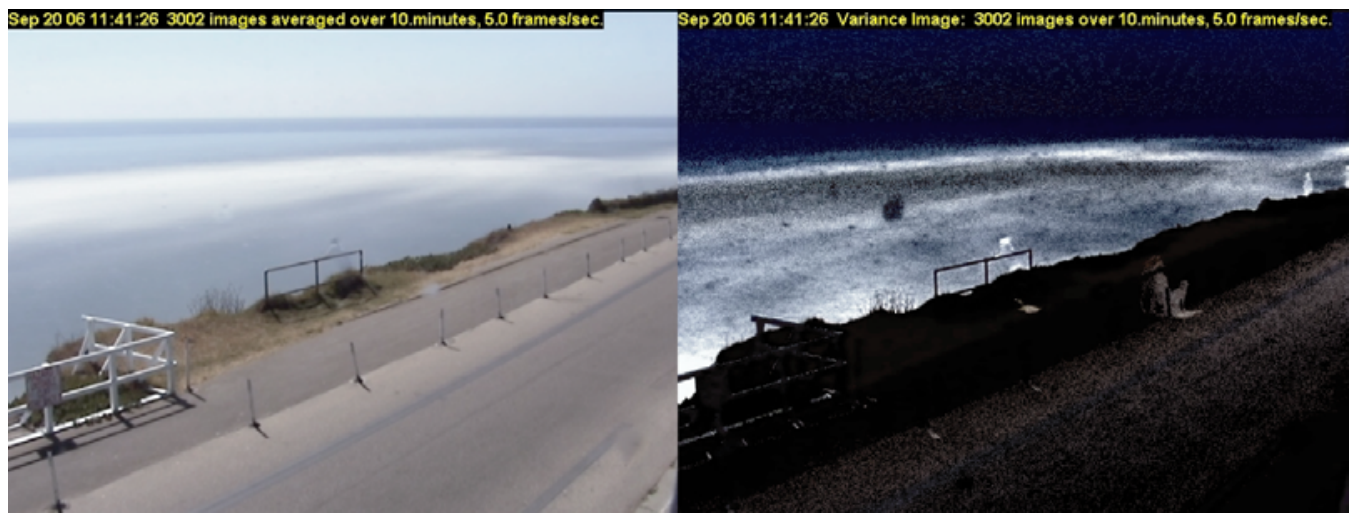

FIGURE 15: Video camera data from a period with larger (1.5 m) waves (09/20/2006). LEFT: Average of more than 3,000 images taken at $5 \mathrm{~Hz}$. RIGHT: Variance of more than 3,000 images taken at $5 \mathrm{~Hz}$. Note the much larger regions of wave breaking and whitewater (wave bores) as compared to the period of smaller waves shown above in FIGURE 14. 


\section{SUMMARY}

The USGS conducted an integrated study to document both the coastal and nearshore morphology and the spatial and temporal variation in waves at Pleasure Point, Santa Cruz County, California. These data were collected by means of three-dimensional beach and seacliff mapping using airborne and terrestrial lidar scanners, nearshore bathymetric surveys using single-beam fathometers and an interferometric side-scan swath bathymetric sonar, video monitoring using a digital still camera and digital video camera and in situ oceanographic measurements using a acoustic Doppler current profiler and directional wave gauge. In all, more than 39 million points of ground topographic data, 3.3 million points of seafloor bathymetric data, 40,000 images of wave breaking patterns and 8,900 in situ directional wave spectra measurements were collected.

These data provide the baseline information needed for future studies directed toward predicting the impacts of stabilization on the seacliffs, beach and nearshore sediment profiles, natural rock reef structures, and offshore habitats and resources.

\section{ACKNOWLEDGEMENTS}

This work was funded by the Santa Cruz County Redevelopment Agency, Santa Cruz County Department of Public Works and the California Department of Boating and Waterways, and the USGS WCMG. The USGS funds were allotted as part of an effort by the Benthic Habitats Project to better understand the affect of geologic and oceanographic processes on nearshore ecosystems. Paul Rodriguez (Santa Cruz County Redevelopment Agency), Ralph Norberg (Santa Cruz County Department of Public Works), and Kim Sterrett (California Department of Boating and Waterways) were the county and state liaisons, and provided support and advice throughout the experiment. We would like to thank residents Liz and Don Darst, who graciously donated their time and effort during our numerous survey operations. Annie, Jim and Joel Marshall overextended themselves by hosting our digital imaging system at their house for 12 months, and for that we owe them great thanks. Brian Foss and the staff at Santa Cruz Small Craft Harbor provided us with launching and loading facilities. We would also like to thank Amy Draut (USGS) and Jon Warrick (USGS), who contributed numerous excellent suggestions and a timely review of our work. Use of trademark names does not imply USGS endorsement of products. 


\section{REFERENCES}

Coastal Services Center, National Oceanographic and Atmospheric Administration, 2006. Online digital data. ftp://ftp.csc.noaa.gov/crs/lidar/load lid.avx

CodaOctopus, 2006. Octopus F180. Technical Brief. Edinburgh, UK

Collins, B.D. and Sitar, N., 2004. Application of High Resolution 3D Laser Scanning to Slope Stability Studies, Proceedings of the 39th Symposium on Engineering Geology and Geotechnical Engineering, Butte, Montana, May 18-21, 2004, pp. 79-92.

Collins, B.D. and Sitar, N., 2005. Monitoring of Coastal Bluff Stability Using High Resolution 3D Laser Scanning, ASCE Geo-Frontiers Special Publication 138:- Site Characterization and Modeling, Remote Sensing in Geotechnical Engineering, E.M. Rathje, ed., ASCE, Austin, Texas, Jan 24-26, 2005.

MacMahan, J., 2001. Hydrographic surveying from a personal watercraft. Journal of Surveying Engineering ${ }_{\mathrm{L}}$ 127(1), 12-24.

National Data Buoy Center, National Oceanographic and Atmospheric Administration, Monterey Buoy \#46042, 2007. Online digital data.

http://www.ndbc.noaa.gov/station page.php?station=46042

National Ocean Service, National Oceanographic and Atmospheric Administration, Monterey tide station \#9413450, 2007. Online digital data.

http://tidesandcurrents.noaa.gov/data menu.shtml?stn=9413450\%20Monterey,\%20CA\&type=Hist oric\%20Tide\%20Data

Ruggiero, P., Kaminsky, G.M., Gelfenbaum, G., and Voigt, B., 2005. Seasonal to interannual morphodynamic variability along a high-energy dissipative littoral cell. Journal of Coastal Research, 21(3), 553-578.

SEA(AP) Ltd., 2005. SWATHplus training pack. Beckington Castle, PO Box 800, Frome England, BA11 6TB. 


\title{
APPENDIX 1
}

\section{Terrestrial Lidar System Information}

\author{
Riegl LMS-Z210 3D Laser Mirror Scanner (S/N: 9992980) Terrestrial Lidar System \\ (http://wwwwriegl.com/terrestrial_scanners/lms-2210i_/210i_all.htm)
}

Technical Description:

Technical Specifications: Physical Dimensions: Range Information Angular extents: Measurement Accuracy: Measurement Resolution: Measurement Rate: Power:

Survey Description:

Survey Schedule:

Position Information:

Position Accuracy:

Processing Information:
Near infrared, Laser Class 1 (eye safe) pulsed laser diode with true color channel operating on time-of-flight measurement principle with panning head and rotating triangular mirror.

$0.5 \mathrm{~m}$ in height, $0.2 \mathrm{~m}$ in diameter, and $13 \mathrm{~kg}$ in mass.

Up to $200 \mathrm{~m}$ typical, up to $700 \mathrm{~m}$ under optimal atmospheric conditions. $0^{\circ}$ to $336^{\circ}$ horizontally, $0^{\circ}$ to $80^{\circ}$ vertically Typically $15 \mathrm{~mm}$ to $25 \mathrm{~mm}$ $5 \mathrm{~mm}$ Up to 8000 points/s One gel cell 12-volt battery running at 6.5 amps (typ.) and 78 watts (typ.).

The lidar unit is set-up on a $1.5 \mathrm{~m}$ adjustable tripod and leveled with a tribrach. Typically, the tripod is located on the beach or intertidal platform and aimed at the seacliffs or located on the seacliff top and aimed over or along the seacliffs. A laptop computer controls the lidar instrument via parallel and serial cables. Each scan typically obtains 1 million data points; collected in approximately 5 $\mathrm{min}$. The equipment is moved along the beach every 50 to $100 \mathrm{~m}$ and the survey is repeated.

Data were collected from the top of the seacliff on October 5-6, 2006, consisting of 37 scans. Data was collected from the beach and intertidal bedrock reef platform on January 27, 2006, consisting of 17 scans. Due to differing beach conditions between these two efforts, only beach data of the lowest beach geometry (January 27, 2006) was utilized in the processed data set. Of these 54 scans, only 46 were utilized due to existing overlapping data or poor registration fit with some of the scans. Additional data adjacent to the Pleasure Point study area (Opal Cliffs area) was collected on February 9, 2006, and January 31, 2007, consisting of 8 additional scans and were utilized in the final georeferencing of the data set.

Data were registered to geodetic coordinates through the collection of 30 local control points visible in the scan data. The local control points were surveyed using a pair of Ashtech Z-Xtreme geodetic quality, dual frequency (L1/L2) GPS receivers. One receiver acted as a base station and the other as a rover located over each control point. The data was post processed differentially using Ashtech's proprietary software in a Stop-and-Go methodology.

Lidar data in January, 2007, were collected using a pair of Topcon Hyper+ RTK, dual frequency GPS/GLONASS receivers using a similar base-rover methodology, but processed in real-time using a Pacific Crest radio link.

The GPS equipment used in the survey program provided local control point accuracies on the order of less than $5 \mathrm{~cm}$.

The GPS/GLONASS equipment used for the January, 2007, lidar surveys provided point accuracies on the order of less than $6 \mathrm{~mm}$.

Data processing was performed using I-SiTE Studio 2.4 and 3.0 software, specifically designed for terrestrial Lidar data processing. Scans were filtered, registered, and georeferenced according to standard post-processing 
techniques. Three-dimensional surfaces and digital elevation models (DEMs) and grids were then extracted from the data. ArcGIS was utilized for final extraction of DEMs using data filtered to a minimum individual point to point separation of $20 \mathrm{~cm}$.

Processing Accuracy:

Individual scans each have an internal accuracy of $2.5 \mathrm{~cm}$. Adjacent scans were registered to one another through local fit of overlapping data typically consisting of several hundred thousand points. Measurements between adjacent scans have an internal accuracy of $5 \mathrm{~cm}$. The internal accuracy of the data for measurements made within the lidar data set is $2.5+5=7.5 \mathrm{~cm}$ or approximately $0.08 \mathrm{~m}$. All scans were georeferenced to NAD83 UTM Zone 10N and NAVD88 coordinates using surveyed control points visible in the scan data. Measurement fit of all data to georeferenced coordinates is $0.5 \mathrm{~m}$.

Internal Horizontal and Vertical Positional Accuracy Assessment: $\pm 0.08 \mathrm{~m}$

Georeferenced Horizontal and Vertical Positional Accuracy Assessment: $\pm 0.50 \mathrm{~m}$ 


\section{APPENDIX 2}

\section{Coastal Profiling System Information}

Vessel Specifics

Description:

Dimensions:

Survey speed:

Instruments:

Power:

Position Information:

Depth Information:

Navigation:

Survey Accuracy:
2003 Honda AquaTrax F-12 4-stroke PWC

$3.2 \mathrm{~m}$ in length, $1.3 \mathrm{~m}$ in width, and $1.1 \mathrm{~m}$ in height

$3 \mathrm{~m} / \mathrm{s}$ ( 6 knots); can operate for $\sim 5$ hours on 60 -L fuel tank

The instruments are placed on a bracket at the stern of the vessel, and forward upper part of the vessel in front of the handlebars. On the stern bracket are three large watertight cases, which house the GPS, computer, echo sounder electronics and batteries.

Two gel cell 12-volt marine batteries, configured in parallel and housed in a Pelican box mounted on the PWC's stern.

Trimble 4700 GPS receiver, with Pacific Crest GPS radio modem to communicate with the shore base station. The L1/L2 microcentered GPS antenna and the radio antenna were mounted directly above the echo sounder transducer.

ESE-50 single frequency echo sounder with a $200 \mathrm{kHz}$ transducer manufactured by Flash Fire Technology, Inc. The transducer has a $10^{\circ}$ conical beam width and generates a pulse at $200 \mathrm{kHz}$. The CPS collected data at $5 \mathrm{~Hz}$ and while traveling at $3 \mathrm{~m} / \mathrm{s}$, generated a depth sounding every 0.6 meters along the sea floor.

HYPACK hydrographic surveying software was used as the data synchronization software and navigation system. Navigation and surveying are aided by a 12 inch Big Bay Technologies outdoor monitor that is mounted in a watertight case on a bracket forward of the PWC's handlebars. A small 17-button programmable Logic Controls keypad is placed in a waterproof radio bag mounted on the handlebars.

The survey-grade GPS equipment used in the monitoring program have manufacturer reported Root Mean Square (RMS) accuracies of approximately \pm 3 $\mathrm{cm}+2 \mathrm{ppm}$ of baseline length (typically $10 \mathrm{~km}$ or less) in the horizontal while operating in Real Time Kinematic surveying mode. The horizontal uncertainty of individual data points is $\sim 0.05 \mathrm{~m}$.

Quantitative Horizontal Positional Accuracy Assessment: $\pm 0.05 \mathrm{~m}$

Quantitative Vertical Positional Accuracy Assessment: $\pm 0.15 \mathrm{~m}$ 


\section{APPENDIX 3}

\section{Swath Bathymetry System Information}

SEA Group Ltd 234 kHz Interferometric Submetix SWATHplus-M Bathymetric Sonar System

(http://www.sea.co.uk/swathplus.aspx?nav=products)

Dimensions $(\mathrm{cm})$ :

Maximum Water Depth:

Maximum Swath Width:

Maximum Range/Depth Ratio:

Across-track resolution:

Accuracy:

Operating Environment:

Data Processors:

Navigation:

Navigation Logging:

Heading Information:

Spatial Resolution:

Data Format:
$16 \mathrm{H} \times 35 \mathrm{~W} \times 6 \mathrm{D}$

$100 \mathrm{~m}$

$300 \mathrm{~m}$

$15: 1$

$7.5 \mathrm{~cm}$ maximum, $1.1^{\circ}$ azimuth beamwidth

$0.1 \mathrm{~m}$ or $1 \%$ accuracy versus water depth

Microsoft Windows NT

SEA Swath Processor, v. 2.05

SEA Grid Processor v. 2.05

CodaOctopus, Model F180, Differential Global Positioning

System (DGPS)

Yo-Nav version 1.19

KVH Industries Inc. azimuth digital gyro

compass provided ship headings with $0.5^{\circ}$ accuracy

$0.2 \mathrm{~m}$ raw, $1.0 \mathrm{~m}$ processed

Correct $x$-position, $y$-position, depth, and acoustic amplitude data

Data Processing:

Started with SXP files that were the output from A $234 \mathrm{kHz}$ Interferometric Submetix Swath Bathy Sonar System. Imported these SXP files on at a time into a SEA Grid Processor v. 2.05, environment with a bin size of 1 (bin size is in meters). In SEA Grid Processor environment ran the following filter on each bathymetry file: Standard deviations $>0.5$. Individually exported each bathymetry file from SEA Grid Processor environment which converts the SXP file to an ASCII grid text file. Imported bathymetry ASCII grid text files into Fledermaus v.6.2.0a, Build 45 Professional, using the Fledermaus Data Magic extension. Exported bathymetry files from Fledermaus Data Magic to ASCII ArcView grid format. In ArcGIS v. 9.1, Toolbox environment, converted ASCII ArcView grid files from ASCII to ArcGIS Raster; defined projection for each raster as NAD_1983_UTM_Zone_10N; and built ArcGIS pyramids for each raster file. In ArcGIS v. 9.1, Toolbox environment, Spatial Analysis Tools-->Math-->Plus tool, added 0.043 to grid depth in order to correct for difference between MLLW and NAVD 88.

Vessel Information:

University of California at Santa Cruz R/V Paragon

32 ' Radon style, twin 250HP diesels, radar, fathometer, autopilot and davit.

SWATHplus-M data acquisition and real-time processing van was installed on the aft deck.

SWATHplus-M transducer was mounted on the starboard side aft quarter. Sound Velocity Profile (SVP) casts were made using an Applied Microsystems SV-Plus V.2 sound velocity profiler off the port side aft quarter. Navigation was provided using the YoNav software package, which allowed for the creation of sets of parallel survey lines of a given length at a given line spacing. The navigation information, including position, speed, heading and distance along the transect line, were provided to the vessel captain via a LCD display.

Survey Information:

Number of Lines: $\quad 97$ (89 straight, 8 shore-parallel)

Water depths: $\quad$ 1-22 m

Sound Velocity Profiles: 11 sound velocity profiles (minimum $=1 /$ day)

Dates:

Mobilization: $\quad$ 10/12/2005 YD285

Survey: $\quad 10 / 13 / 2005$ YD286 - 10/14/2005 YD287, 10/17/2005 YD290 - 10/19/005 YD292

Demobilization: 10/20/2005 YD293 
Quantitative Horizontal Positional Accuracy Assessment: $\pm 0.2 \mathrm{~m}$

Quantitative Vertical Positional Accuracy Assessment: $\pm 0.3 \mathrm{~m}$ 


\section{APPENDIX 4}

\section{Acoustic Doppler Current Profiler}

Nortek $1 \mathrm{MHz}$ AWAC (S/N: 2074) Acoustic Doppler Current Profiler and Directional Wave Gauge (http://www.nortekusa.com/hardware/AWAC.html)

Transmitting Frequency:

Depth of Transducer:

Blanking Distance:

Height of First Bin above Bed:

Bin Size:

Number of Bins:

Sampling Frequency:

Profile Ensemble Interval:

Profile Averaging interval:

Wave Ensemble Interval:

Number of Wave Samples:

Sound Speed Calculation:

Velocity Precision:

Coordinate System:

Compass Update Rate:

Magnetic Compass:

Location Latitude:

Longitude:
$1 \mathrm{MHz}$

$13 \mathrm{~m}$

$0.4 \mathrm{~m}$

$1.0 \mathrm{~m}$

$0.5 \mathrm{~m}$

34

$2 \mathrm{~Hz}$ surface tracking, $1 \mathrm{~Hz}$ currents

0:20:00.00

0:06:00.00

1:00:00.00

1024

Set salinity (35 PSU), updating temperature via sensor horizontal: $0.5 \mathrm{~cm} / \mathrm{s}$, vertical: $1.4 \mathrm{~cm} / \mathrm{s}$

East-North-Up

0:20:00.00

Set to $-10^{\circ}$ magnetic offset

N $36^{\circ} 56.907$

W $121^{\circ} 58.722^{\prime}$

Data Processing:

The data were averaged into 1 hour ensembles, all of the spurious data above the water surface were removed and all of the data in bins where the beam correlation dropped below $70 \%$ were removed for visualization and analysis.

Position Information:

Garmin GPS-76 GPS; s/n: 80207465 


\section{APPENDIX 5}

\section{Digital Imaging System Information}

Erdman Video Systems, Inc. C5050-PT Biscut with Real-Time Video Upgrade

(http://wwWw.video-monitoring.com/allinone $h$ tm)

Digital Camera:

Digital Video:

Control Interface:

Camera Scene Sampling Frequency:

Number of Camera Scenes:

Video Scene Sampling Frequency:

Number of Video Scenes:

Location Latitude:

Longitude:

Position Information:
Olympus SP-350 Ultra Zoom camera

Sony FCB-EX480A Block camera

667 megahertz embedded PC with 256 megabytes

PC133 memory and 100 gigabyte hard drive

1 per hour

9

5 frames/s for $10 \mathrm{~min}$

4

$\mathrm{N} 36^{\circ} 57.407^{\prime}$

W $121^{\circ} 58.254$

Garmin GPS-76 GPS; s/n: 80207465 


\section{APPENDIX 6}

\section{Experiment Personnel}

\begin{tabular}{|l|l|l|}
\hline \multicolumn{1}{|c|}{ Person } & Affiliation & \multicolumn{1}{|c|}{ Responsibilities } \\
\hline Curt Storlazzi & USGS & Chief Scientist \\
Patrick Barnard & USGS & CPS Survey \\
Michael Boyle & USGS & Swath Bathymetry Acquisition \\
Bradley Carkin & USGS & Terrestrial Lidar Survey Assistant \\
Brian Collins & USGS & Terrestrial Lidar Survey \\
Jodi Eshleman & USGS & CPS Survey Processing \\
Jared Figurski & UCSC & Vessel Captain, R/V Paragon \\
David Finlayson & USGS & Geospatial Data Processing \\
Nadine Golden & USGS & Geospatial Data Processing \\
Dave Gonzales & USGS & Oceanographic Instrumentation \\
Jamie Grover & UCSC & Vessel Captain, R/V Paragon \\
Gerry Hatcher & USGS & Swath Bathymetry Acquisition \\
Robert Kayen & USGS & Terrestrial Lidar Survey \\
Joshua Logan & USGS & Geospatial Information, diver \\
Diane Minasian & USGS & Terrestrial Lidar Survey Assistant \\
Kevin O'Toole & USGS & Mechanical Fabrication/Field Support \\
Kathy Presto & USGS & Oceanographic Instrumentation \\
Tom Reiss & USGS & Dive Safety Officer, Geodetic Survey \\
Peter Ruggiero & OSU & CPS Survey \\
Randy Russell & USGS & Computer Support \\
Randolf Skovan & UCSC & Vessel Captain, R/V Paragon \\
Andrew Stevenson & USGS & Geospatial Data Processing \\
\hline
\end{tabular}

